\title{
Rhetorical Figures: The Argumentative "Ornament"
}

\author{
Ying Yuan ${ }^{1, *}$, Yan Jiang ${ }^{2}$ \\ ${ }^{1}$ School of Foreign Languages, Soochow University, China \\ ${ }^{2}$ SOAS University of London, UK
}

Copyright $\bigcirc 2018$ by authors, all rights reserved. Authors agree that this article remains permanently open access under the terms of the Creative Commons Attribution License 4.0 International License

\begin{abstract}
This essay attempts to demonstrate, via surveying 10 classics in the history of rhetoric, that "ornament" collocated with rhetorical figures is widely viewed as inventional or argumentative, especially from ancient Greece to the Renaissance. Further, 5 representative dictionaries illustrate that this term gives priority to useful function in and before the medieval time but turns increasingly aesthetic from the Enlightenment downwards. In a historical-linguistic perspective, the semantic change of "ornament" is discovered to involve two tendency types: "Narrowing" and "Pejoration", which can be attributed to psychological or cognitive factors, cultural impact and language contact. This rectification of "ornament" justifies from etymology and history of rhetoric that rhetorical figures, deserving a fairer repute, are indeed our flashing argumentative equipment.
\end{abstract}

Keywords Ornament, Argumentative, Rhetorical Classics, Etymology, Historical Linguistics

\section{Introduction}

Figures of speech, whether tropes or schemes, are often disdained as playing the flowery role of ornament/adornment/embellishment, since these terms most frequently appear both in classics and textbooks throughout the history of rhetoric. True, they do often show up, but a close examination of some representative works before the $19^{\text {th }}$ century will reveal that the meaning of these terms is far less confined to the modern stereotypical interpretation. This rectification of "ornament" is not without significance, as it will prove from the rhetorical tradition itself that figurative language, our flashing argumentative equipment, deserves a much fairer judgment and reputation.

We will start with a brief account of the previous scholarships attending to this phenomenon before conducting a rather elaborate survey of no less than 10 landmarks from the Greco-Roman, down the Middle Ages, the Renaissance, and to the early Enlightenment. Their typical interpretations or illustrations of "ornament" will be scrutinized for comparative or interrelated analyses, followed by a historical linguistic approach to tracing the laws and possible causes of this term's semantic change.

As mentioned, in addition to "ornament", there are several synonyms appearing frequently in the English versions of the rhetorical classics. Comparatively speaking, "ornament" possesses the richest semantic dimensions, covering all the meanings of the others, as shown in The Oxford English Dictionary and Webster's Third New International Dictionary. And in the first English Rhetoric book, Thomas Wilson's The Arte of Rhetorique (1553), one type of figures is named "ornaments", so we choose this term as our major object of examination, while occasionally using its synonyms, due to the translated versions. And "argumentative", is meant here as contributing to "the communicative process of advancing, supporting, criticizing, and modifying claims so that appropriate decision-makers, defined by relevant spheres, may grant or deny adherence."

\section{Previous Scholarship}

The striking contrast between the classical and the modern "ornament" has been noticed by quite a few observant rhetoricians. Sister Joseph, in her ground-laying work on figures, surveys briefly the logical association of "ornament" in the Renaissance and before. She finds that to Aristotle, "Ornament is attained by induction and distinction of things" (Topics, 8. I.I $57^{\mathrm{a}} 7$ ), to Hermogenes, enthymemes are "embellishments", to Cicero, "ornament apart from thought involves an unnatural separation", and to Renaissance authors, figures of thought are "ornamentes of matter" (1947, pp. 39-40). Walter Ong, in examining Renaissance rhetoric represented by Ramus, notices that "the first meaning of ornamentum in Latin...is equipment

\footnotetext{
${ }^{1}$ This definition of "argumentation" is offered by Rieke, R. D. \& Sillars M. O. in Argumentation and Critical Decision Making ( $5^{\text {th }}$ ed., New York: Longman, 2001, p. 2). After examining various definitions on this term, we find that Rieke \& Sillars' is more comprehensive, and thus its corresponding adjective can be more interpretative in our context.
} 
or accoutrements" and offers two typical examples: "the fifteenth century can conceive of the hand as 'a great help and ornament to the body,' and the sixteenth century of tackling as the 'ornaments of a ship."' (1958, p. 277). Ong also mentions a neglected dimension of this notion as "praise" or "honor" or "light" (ibid: 278) of speaking, which, inherited from Cicero and Quintilian, still exists in the Renaissance time. Dyck (1966, p. 88) discovers that in the $17^{\text {th }}$ century German rhetorical books, "ornatus" is meant "Wirkung" (effect/function), employed to arouse the audience's emotions. Kennedy in Quintilian touches upon the Roman understanding of "ornament", "a vital and useful quality", which "suggests distinction and excellence, the possession of resources ready for any challenge" (1969, p. 81). In the same year, Griffin, with reference to Cicero, Quintilian and Ong (1958), also realizes the complexity of this term. In commenting on Du Bellay's debt to rhetoric, he reveals that "poetic ornaments" should be "constructs for a varied poetic affect that one can roughly identify, not just in ornamenting verse at random or in having static embellishments" (1969, p. 49). Ornament here is considered to be functional in triggering emotions rather than sheer decoration; besides, he also notices its other functions in Du Bellay's Defence et Illustration, "in numerous instances the meaning of ornament extends to enhanced personal qualities and thought itself" (ibid: 48), where this notion is also linked unmistakably to ethos and logos. In the past three decades, a continuing attention lasts, though not with many rhetoricians. Vickers $(1988$, p. 314) points out the sharp contrast between the Roman weapon-like "ornatus" and the English "'ornament', with the unfortunate connotation of 'adornment', the use of unnecessary trappings or incidental decoration." Fahnestock in her landmark work (1999) claims, "The Latin ornamentum also means furniture, apparatus, and equipment, so that 'ornament' may be more closely related to the notion of essential gear or 'armament' than it is to adornment." (p. 18) She cites supporting examples in Rhetorica and Herennium, Henry Peacham and Martianus Capella's works as evidence of this weapon dimension.

These researches, with suggestive traces or proofs, have contributed to the awareness of the complex semantics of "ornament". However, almost all of them cover this issue rather briefly, with several lines or paragraphs in passing; no treatises seem to have been published solely on this topic yet. The proofs shown above are still meager and mainly confined to a few classics in the Roman and Renaissance periods. So we feel that this topic needs to be systematically inquired to provide adequate evidence for the argumentative dimension of "ornament", and to interpret or account for its semantic change in the rhetorical history. These two objectives are what we mainly attempt to fulfill, with the hope that this exploration will help rectify the overwhelming decorative dimension of "ornament", and moreover, set its collocated rhetorical figures (tropes and schemes)--further free from their narrow unfair cage.

\section{Evidence from Rhetorical Classics (Ancient Greece to the $18^{\text {th }} \mathrm{C}$ )}

The following will examine at least two classics in each period of our surveying span, except for the Enlightenment in which we are able to find just one representative. With regard to the Greek works as early as Gorgias's, we surprisingly discover that "adornment" in The Encomium of Helen almost stands for the core or essence of the described, as apparently shown in the quasi-poetic English translation (with the original format) by Dillon \& Gergel (2003, p. 76):

[J] The adornment $\left(\operatorname{kosmos}^{2}\right)$ of a city is manpower,

Of a body, beauty,

Of a soul, wisdom,

Of an action, virtue,

Of a speech, truth;

And the opposites of these make for disarray (akosmia). ${ }^{3}$

Here, in addition to beauty, "adornment" is also regarded as functioning "wisdom", "virtue", or "truth", etc., the most essential of its subject, being so hugely different from the present day interpretation. ${ }^{4}$

Gorgias is not the only astonishing Greek. Isocrates' Against the Sophists actually offers us similar evidence (in Norlin's translation):

But to choose from these elements those which should be employed for each subject, to join them together, to arrange them properly, and also, not to miss what the occasion demands but appropriately to adorn the whole speech with striking thoughts and to clothe it in flowing and melodious phrase--these things, I hold, require much study and are the task of a vigorous and imaginative mind... (1929, pp. 173-5)

In this passage, "adorn" need be understood as "highlight", or "striking thoughts" as "ornaments of the whole speech", which indeed resembles Gorgias' "truth" as "the adornment of a speech". We can thereafter conclude that Isocrates' "adorn [ment]" concerns no less essence of

\footnotetext{
2 According to OED, "cosmos" in Greek has one meaning of "ornament" (Simpson \& Weiner 1989, III, p. 986).

${ }^{3}$ George Kennedy's version: "I. What is becoming to a city is manpower, to a body beauty, to a soul wisdom, to an action virtue, to a speech truth, and the opposites of these are unbecoming." (Bizzell \& Herzberg, 2001, p. 44) Here, "What is becoming", though phrased differently, is similar to "Ornament" in meaning.

${ }^{4}$ We find a similar case in Lucan's Pharsalia (VII., of Brutus): Oh, ornament of the empire, last hope of the Senate, Latest offspring of a family glorious in history,

Rush not so rashly into the enemy's center lines-

Seek not to hasten the fates not due till Philippi

And to forestall your own Thessalia. Nor will your plan

'Gainst Caesar's life here count for aught; Not yet has he

Attained a tyrant's power. (as cited in Alberic, 1973, p. 152)
} 
the matter. ${ }^{5}$

The Roman classics can provide us with further proofs. [Cicero]'s Rhetorica ad Herennium, the first systematic work on figures of speech, illuminates the argumentative "exornationem" (ornament/embellishment) in the following paragraphs:

The most complete and perfect argument, then, is that which is comprised of five parts: the Proposition, the Reason, the Proof of the Reason, the Embellishment, and the Résumé. ... Embellishment we use in order to adorn and enrich the argument, after the Proof has been established. (1981, pp. 107-109)

Here, "Embellishment" ("exornationem" in Latin origin), is itself a component of argument, and this argument-oriented adorning is even more explicitly illustrated in "Embellishment consists of similes, examples, amplifications, previous judgments, and the other means which serve to expand and enrich the argument" (ibid: 141). This tune of embellishment is resonated down through ${ }^{6}$ till the ending chapter of the entire work:

I have here carefully collected all the principles of embellishing style. If, Herennius, you exercise yourself diligently in these, your speaking will possess impressiveness, distinction, and charm. As a result you will speak like a true orator, and the product of your invention will not be bare and inelegant, nor will it be expressed in commonplace language (ibid: 409).

In these lines, we see at least three functions mentioned as generated by "embellishing" or "adorning": "impressiveness, distinction, and charm" with the two more argumentative roles going before and they are all intended to serve the purpose of "invention" or argument. Bearing similarity to Isocrates, though not so sharp as Gorgias, the author of ad Herennium definitely charts a broad span for his notion of embellishment/ornament.

His Roman follower, Quintilian, seems to offer a clearer picture for this term. In The Institutio Oratoria, he hails "ornament" as "flashing weapons", which "appeals to the

\footnotetext{
${ }^{5}$ We also find that Aristotle treats in Topica (related to his Rhetoric) "ornament" and "adorn" in a like manner: "..for ornament, you should employ induction and the distinction of things of a closely similar kind. What induction is, is obvious; distinction is attained by statements such as that one science is better than another, either because it is more exact or because it is concerned with better objects, and that some sciences are theoretical, others practical and others creative. Every distinction of this kind helps to adorn your argument, though its introduction is not necessary to the conclusion." (VIII, , translated by E. S. Forster) This is taken from Posterior Analytics, Topica (Cambridge: Harvard University Press, 1960, pp. 685-7).

${ }^{6}$ There appears an ambivalent resonation in distinguishing types of figures (IV. XIII): “To confer distinction upon style is to render it ornate, embellishing it by variety. The divisions under Distinction are Figures of Diction and the Figures of Thought. It is a figure of diction if the adornment is comprised in the fine polish of the language itself. A figure of thought derives a certain distinction from the idea, not from the words." (1981, p. 275) But in his illustration of the figures of diction, argumentative functions show up not infrequently.
}

enthusiastic approval of the world at large" (BVIII. III. 2-6; 1921, Vol. 3, p. 213). And these ornament weapons fulfill at least three interrelated tasks:

The ornate is something that goes beyond what is merely lucid and acceptable. It consists firstly in forming a clear conception of what we wish to say, secondly in giving this adequate expression, and thirdly in lending it additional brilliance, a process which may correctly be termed embellishment. (ibid: 60-63; p. 245)

Briefly put, the tasks or functions in his definition of "[t]he ornate" are to achieve clarity of thought, adequacy in expression, and embellishment or brilliance. So we see that in Quintilian's many-layered semantics of "ornament", the narrow sense of "embellishment", though rather outstanding, occupies one third of it, at most.

In the Medieval time, the Venerable Bede (c. 673-735)'s De schematibus ET tropis (Concerning Figures and Tropes c.700), England's first treatise on Style, provides us with more traces of the argumentative "ornament/ embellishment”. Before specifying his 17 schemes and 28 tropes, he generalizes their functions as follows (Bede, 1973, p. 97):

It is quite usual to find that, for the sake of embellishment, word order in written compositions is frequently fashioned in a figured manner different from that of ordinary speech. The grammarians use the Greek term "schema" for this practice, whereas we correctly label it a "manner," "form," or "figure," because through it speech is in some way clothed or adorned. Metaphorical language is also quite commonly found when, either from need or for adornment, a word's specific meaning is replaced by one similar but not proper to it. (tran. G. H. Tannenhaus)

Here in describing the functions of both figures/ schemes and tropes, Bede uses "embellishment" and "adornment", which at first glimpse seem rather decorative; however, a further check of his illustration (as shown in Periphrasis) gives us a clearer picture:

Periphrasis is a circumlocution, and is used either to embellish and expand a simple idea or to avoid the direct mention of an unpleasant subject. An example of Periphrasis used to embellish a simple idea is the following (II Cor. 5:1): For we know that if the earthly house of our tabernacle be dissolved, we have a building from God, a house not made with hands, eternal in the heavens. (ibid: 112)

In this context at least, Bede's "embellish" collocated with "idea" is no other than "enrich" or "extend", which is apparently argumentative. And his typical example of "Periphrasis" leaves us with no doubt.

The Italian Alberic of Monte Cassino's Flores rhetorici/ 
Flowers of Rhetoric (c.1087), ${ }^{7}$ provides us with no less forceful evidence. The beginning of Chapter 5 where he starts to concentrate on the discussion of figures shows us some rather obvious traces.

Let us move on, then, to that which enhances propriety and embellishes the composition. Let us, I mean, move on to those techniques which good Latin usage recognizes as figures. Granted that they are not of themselves necessary at all, yet by virtue of their own properties they add a degree of nobility, since they enhance, develop, improve, and illumine good style.

First, adornment is added to a piece of writing in this way, when an idea is repeated for effect in one sentence. This will be clear in an example (Vergil, Aeneid X.149):

He approaches the king; he makes known to the king his name and his family. (Alberic, 1973, p. 143)

In the above paragraphs, we see "embellish [ment]" and "adornment" play the ethotic function of adding "a degree of nobility" as well as the logical function of effectively repeating "an idea", two major persuasive appeals in Aristotle's invention. Apart from them, we also discover the apparent function of pathos generated by figures as shown below:

No less attention should be given to seeing that the style is touched up, as it were, by certain little flourishes. Whenever an idea is presented in this way, when a suggestion of these touches is applied, a writer can emphasize what is good, guide the wise with his advice...he can oppose the arrogant, he can console the wretched. Moreover, he can love, praise and extol virtue, detest, spurn, and totally disavow the vices. (ibid: 151)

To Alberic, the application of "touches"/ornaments via "flourishes"/figures not only fulfills the logical and ethical functions of guiding soundly and judging morally, but can also effectively tame strong emotions, such as "oppos[ing] the arrogant", and "consol[ing] the wretched".

Thomas Wilson (1524-1581) of the Renaissance has shown us still stronger evidence. In The Art of Rhetoric (1553), while discussing the three types of figures: tropes, schemes, and colours, he unquestionably mentions the inventional or argumentative functions as manifest in explaining the last figure type--colours:

[T] he third is when by diversity of invention a sentence is many ways spoken, and also matters are amplified by heaping examples, by dilating arguments, by comparing of things together, by

\footnotetext{
${ }^{7}$ According to its translator J. Miller, it is "the first work formally linking the ancient art of discourse and the new art of correspondence"(ibid: 131).
}

similitudes, by contraries, and by divers other like, called by Tully exornation of sentences or colors of rhetoric. (1994, pp. 195-6)

When illustrating his third type of figures, Wilson also uses "Ornaments" (ibid: 203) to refer to it. ${ }^{8}$ And we find that almost all of his 36 ornaments are no other than argumentative strategies or means, such as "Resting upon a Point", "Witty Jesting", "Digression", "Proposition", "Correction", "Example", "Fables", etc. In their illustration, he repeatedly uses the terms like "augment" and "persuade". For instance, Correction--altering the expression other than the previous--purposes "thereby to augment the matter and to make it appear more vehement" (ibid: 211). In terms of "Example" and "Fables", Wilson stresses respectively, "He that mindeth to persuade must needs be well stored with examples."; and "For not only they delight the rude and ignorant, but also they help much for persuasion." (ibid: 215, 221) Actually, the argumentative function is not confined to the figure type of colours, but pervasive as well in his discussions of the other two types (tropes \& schemes). So Peter Medine, the editor of the modernized version, concludes in the "Introduction" that "He [Thomas Wilson] almost never analyzes the figures specifically in terms of ornament [the narrow sense at the present time] or decoration." (1994, p. 22)

Wilson's contemporary, Henry Peacham, does not write without similar remarks. In The Garden of Eloquence (1577), "[t]he greatest English work on the figures" (Fahnestock, 1999, p. 13), it is quite common for us to see "ornament" and its synonyms in Peacham's description of the figures; a case in point is Antithesis:

This is a most excellent ornament of eloquence, serving most aptly to amplification, it graceth and bewtifieth the Oration with pleasant varietie, and giveth singular perspicuitie and light by the opposition, it is so general that it may serve to amplifie and garnish any grave and weightie cause. (1593, p. 161)

Here, "ornament" not only plays the function of gracing and beautifying, but also of achieving perspicuity and amplification to which it serves "most aptly". The last clause unmistakably shows us that this ornament of antithesis plays the two combined roles of "amplif[ying] and garnish[ing]", the desirable two-in-one effect.

In the late Renaissance, Bernard Lamy (1640-1715) in his De L'Art de Parler / The Art of Speaking (1675), time and again employs the term "Ornament" with the argumentative dimension. As shown in Part 2, Chapter 2,

\footnotetext{
${ }^{8}$ Wilson's division of the figures, besides Tully, may also be influenced by Melanchthon's Elementorum Rhetorices Libri Duo (1534), as within the latter's schemes, there is a subtype called "figures of ornament", but due to the lack of its English version, we don't know the specifics of its discussion. According to Medine's related comment, for Melanchthon, "the argumentation and adornment of eloquent statement become virtually one" (Wilson, 1994, p. 13)
} 
Section 3 is entitled "Tropes are an Ornament to Discourse", for which he illustrates:

Tropes do make a sensible description of the thing we intend: When we call a Great Captain The Thunderbolt of War, the Idea of Thunder informs pleasantly with what force, with what swiftness, with what noise, the said Captain overcomes: Men do not commonly receive any thing into their Minds, that comes not first to their Senses. ${ }^{9}$

This remark compels us to feel that, to Lamy, the trope ornament should mainly function as vivaciously conveying the intended meaning, a kind of argumentative function. ${ }^{10}$ In fact, he is strongly against the abuse of the ornament "introduc'd only for Imbellishment" (Harwood, 1986, p. 334), so in "Of Artificial Ornaments: Rules relating to those Ornaments" (Part 4, Ch. 4, Section 3), he sets four strict rules: "apply them in their due time and place"; "the Ornaments be just"; "consider first what is useful"; "keep a just Moderation in our Ornaments" (ibid: 334-6). Among them, the first consideration of ornaments' usefulness deserves our particular attention. Lamy's sharp argumentative sense of figures is further displayed in these summarizing lines:

For my own part I value not the Art of Speaking, but as it contributes to the discovery of truth; as it forces it from the bottom of our thoughts where it lay conseal'd; as it disentangles it, and displays it to our eyes; and indeed this is the true cause that has incouraged me to write of this Art, as a thing not only useful, but necessary. (ibid: 337)

Far beyond being decorative, Lamy's “Art of Speaking”, "Ornaments"/Figures (in this context), is definitely inventional or argumentative, due to its strong powers of discovering, revealing, disentangling, and displaying"truth".

The plainness-oriented Enlightenment is actually a turning point of attitudes towards rhetorical figures. We find it hard to locate typical works with similar conception on "ornament", but at least Hugh Blair's Lectures on Rhetoric and Belles Lettres (1783) still displays certain traces. The Scottish rhetorician, treating figures as "the ornament of Style" (1819, p. 263), emphasizes that of all their four functions, ${ }^{11}$ the most prominent is giving us frequently a much clearer and more striking view of the

\footnotetext{
9 This is taken from 1676 English version, edited and noted by Harwood (1986, p. 222), so the language bears Renaissance English character, e.g. capitalization for nouns here and spellings different from now, such as "incouraged" in the following citation.

${ }_{10}$ To be specific, the trope here contributes to the advancing of the claim that the captain is of extreme valour; the following quotation illustrates the similar argumentative function (cf. Note 1).

${ }^{11}$ The other three functions appear in Volume One, Lect. XIV are: "First, They enrich Language, and render it more copious....Secondly, They bestow dignity upon Style....In the third place, Figures give us the pleasure of enjoying two objects presented together to our view, without confusion; the principal idea, which is the subject of the discourse, along with its accessory, which gives it the figurative dress." $(1819$, pp. 275-7)
}

principal object, than we could have if it were expressed in simple terms, and divested of its accessory idea. This is, indeed, their principal advantage, in virtue of which, they are very properly said to illustrate a subject, or to throw light upon it. (ibid: 277)

So to Blair, the ornaments of figures, though not without their beautifying effect as shown in other functions, need to fulfill, above all, an inventional or argumentative duty of illustrating or lighting up a subject; as a result, "even conviction is assisted, and the impression of a truth upon the mind made more lively and forcible" (ibid: 278). But maybe influenced by the Enlightenment Movement, his Belles Lettres occasionally shows traces of degrading the figure/ ornament as well. ${ }^{12}$

The above survey is by no means exhaustive; it only concerns the classics written in or translated into English. We actually have detected certain clues in some non-English works, such as Melanchthon's Elementorum Rhetorices Libri Duo (1534), Bouhours La manière de bien penser (1687), and Mayans' Retórica (1757), ${ }^{13}$ but being unable to find their English versions, we have to give them up for this investigation. Moreover, even for the English source, we are far from making a thorough speculation of the related classics for all the convincing evidence. Yet, what we have provided can justify the conclusion that in a long historical time, especially from Ancient Greece to the Renaissance, "ornament" as inventional or argumentative is widely accepted and commonly held with a considerable prestige, almost incredible to the modern minds.

\section{Etymological Proofs from Dictionaries}

Besides the encouraging evidence from the rhetorical classics, widely acclaimed dictionaries may serve as a complementary source for traces in etymology. The following will closely examine five representative dictionaries, three comprehensive and two specialized, to detect both the functional trace of our "ornament" and the evolutionary track of its semantic change.

In The Oxford English Dictionary (2nd ed.), there list three meaning groups of "ornament"; examined here are all the "a" meanings for each group. Meaning 1. a. "Any adjunct or accessory (primarily for use, but not excluding decoration or embellishment); equipment, furniture, attire, trappings." Analyzing this first of the first meanings, we see unmistakably that being useful is the most prominent function (though the accessory may be decorative as well).

\footnotetext{
12 But Blair's other remarks may sound rather ambivalent, such as "Figurative Language, over and above, bestows a particular dress upon that idea; a dress which both makes it to be remarked, and adorns it (ibid: 265)." And "The Figure is only the dress; the Sentiment is the body and the substance (p. 267)."

${ }^{13}$ Cf. Conley, Thomas. Rhetoric in the European Tradition (1990, pp. 199, 209 ) for D. Bouhours and G. Mayans respectively.
} 
OED offers examples from the years of 1225-1747. As the early ones are in Latin or old English, we select two examples in the Renaissance: "1565-73. The tackling or ornaments of a ship"; "1611 CHAPMAN Iliad XI. 450 A surgeon is to be preferr' $\mathrm{d}$, with physic ornaments, before a multitude." (Simpson \& Weiner 1989, X, p. 939) The "ornaments" in these two are definitely more functional than decorative; in either case, they are actually equipment of utter necessity. However, the next two meanings, in brief, are decoration-oriented: Meaning 2. a. "Something employed to adorn, beautify, or embellish, or that naturally does this" (examples given from 1388-1969); and Meaning 3. a. "The action of adorning or fact of being adorned" (examples starting from 1596). In these two meanings, the interpretive "adorn", or "embellish" is equivalent to "beautify", different from what we have examined in the above classics. It is no wonder, then, that modern English "ornament" is associated so tightly with the narrow sense of adornment or embellishment.

This tendency of the usefulness of "ornament" gradually giving way to embellishment is strongly felt in Samuel Johnson's A Dictionary of the English Language. In its similar 3 meanings on "ornament", we discover with no less surprise that the order is in complete reversal of the above: "1. Embellishment; decoration."; "2. something that embellishes."; "3. Honour; that which confers dignity." (1827, II, p. 15) Here, the two meanings concerning beautification are treated as more prominent or popular; and this should be the case in Johnson's $18^{\text {th }}$ century British English. Not long after, American English displays its similar tendency. In Webster's Third New International Dictionary (originating from 1828) ${ }^{14}$, although the sequencing of the meanings is the same as that in OED, the first meaning--“a useful accessory"--is labeled as "archaic" (Gove, 2002, p. 1592), which implies its insignificance for current English. All these dictionaries, one way or another, offer us certain traces of the semantic evolution of "ornament", from being mainly useful to almost entirely beautifying.

The specialized Chambers Dictionary of Etymology, the most elaborate of its kind we can find, will provide us with further clues of period for each dominant meaning. It shows that the first meaning ("useful accessory") is prevalent "[p]robably before 1200 " with the spelling of "urnement", and this meaning survives in the Renaissance, but in the meantime, decoration or embellishment exists side by side with it all through the periods, while the last meaning ("act of ornamenting") appears rather late, to be specific, "first recorded in English in 1860, in J. S. Mill's writings" (Barnhart 1966: 737). So we guess that the appearance of the last meaning might be a turning point of narrowing the inclusive equipment-centered "ornament"

\footnotetext{
${ }^{14}$ According to Philip Gove's "Preface", this is "the eighth in a series which has its beginning in Noah Webster's American Dictionary of the English Language, 1828" (2002, p. 4a).
}

to mere adornment which is expected to be more beautiful than useful. The more recent The Oxford Dictionary of Word Histories, though not so elaborate, provides us with extra clues:

Ornament [Middle English] Early use included the sense 'accessory'. It comes from Old French ournement, from Latin ornamentum 'equipment, ornament', from ornare 'to adorn'. The verb dates from the early $18^{\text {th }}$ century. (Chantrell, 2002, p. 355)

Here, we see this term's family history: from Latin to Old French to Middle English, then modern English. Its first origin is Latin "ornamentum" which includes both "equipment" and "ornament" (maybe in the decorative sense). At the early English in the Middle Ages, it retains the meaning of "accessory"/"equipment", the functional dimension. But the entry seems to imply that its later use gradually loses this sense.

We thus have the reason to conclude, in combination with what we have proved previously, that at least before the $13^{\text {th }}$ century, "useful accessory" is a widely accepted (possibly dominant) semantic dimension for "ornament", and around the Renaissance time which has been much influenced by the Greco-Roman period, this first meaning has been basically maintained and not lost until around the nineteenth century.

\section{Historical Linguistic Interpretation}

With the semantic changes of "ornament" proved by both the classics and dictionaries, come our further inquiries--whether there are interpreting laws behind it and why such a change has happened. Historical linguistics, dealing with all sorts of language change, appears the most promising approach to solving our curiosities. As to semantic change in particular, various change types have already been justified, of which we prefer the rather terse summary by Fortson (2003): "Metaphoric extension", "Metonymic extension", "Broadening", "Narrowing", "Melioration", "Pejoration". ${ }^{15}$ The semantic change of "ornament" seems to have displayed the law of narrowing as well as certain pejoration (tending to be more negative). For either of the two laws, we see similar cases to our "ornament". With the narrowing of meaning, for example, in old English "deor" refers to "animal" in general, not merely "deer", and "corn" means "grain", not confined to "maize" or "oats" (Traugott \& Dasher, 2002, p. 56); with the negative tendency, for instance, "mistress" undergoes

\footnotetext{
15 These 6 change types summarized by Fortson are taken from "Table 1. Classifications of types of semantic change from a sociolinguistic point of view" in Crespo $(2013$, p. 81$)$, actually an echoing of the classification in Michel Bréal's pioneering work, Essai de Semantique (1897): "pejoration vs. amelioration, restriction vs. expansion, metaphor vs. metonymy" (cited in Traugott \& Dasher, 2002, p. 54).
} 
"head of household $>$ woman in continuing extra-marital relationship with a man", and "bourgeois", the process of "resembling the French middle class $>$ philistine". "Ornament" not only experiences the reduction from the inclusive meaning of accessory both useful and beautiful to the mere beautifying decoration, but now it is also tinted, not infrequently, with some disdaining connotation.

So we see that the semantic change of "ornament" is not a rare case in historical linguistics, yet it is a more complicated one (with two changes together). More significant, then, is how to account for this phenomenon. From Michel Bréal (1897) down to the present scholarship, generally two major types of causality have been mentioned: internal and external. The former mainly concerns the psychological and cognitive factors, such as avoiding difficulty, securing greater clarity; the latter involves social ones, e.g. political or cultural changes, and language contacts (cf. Crespo, 2013, p. 48; Traugott \& Dasher, 2002, pp. 58-59). To the semantic change of "ornament", we think both internal and external factors, and even the interaction of them, have made contributions. The original meanings of "ornament" are too inclusive and context-dependent, requiring extra attention for the mental or cognitive processing; by and by, the word tends to be assigned with fewer dimensions so as to play its role efficiently. Then why does the dimension of usefulness get more and more diminished, other than that of beautification? This could be explained from the external factors, mainly cultural or ideological impact, and language contact. We claim that the Enlightenment Movement, advocating utility and plain language, may be most responsible for the modern interpretation of "ornament", especially when it is collocated with rhetorical figures. ${ }^{16}$ Descartes, Locke, Kant, to name just a few; have all severely attacked figurative language. Locke, in "An Essay Concerning Human Understanding", bombards the most deadly shell,

All the art of rhetoric, besides order and clearness, all the artificial and figurative application of words eloquence hath invented, is for nothing else but to insinuate wrong ideas, move the passions and thereby mislead the judgment; and so indeed are a perfect cheat. (France, 2006, p. 499)

And not just individual philosophers, some academic societies as well have shown apparent contempt, even "indignation" at the ornaments, such as the British Royal Society, "Who can behold, without indignation, how many mists and uncertainties these specious tropes and figures have brought on our knowledge?" (ibid: 498) Under such critical shells and storms from both the

\footnotetext{
${ }^{16}$ This claim is still in lack of adequate evidence, as the learned peer reviewer pointed out, "language had been at the centre of a fiery debate for at least 200 years: the controversy about the language of Elizabethan playwrights or on the plain style in the XVII century was exactly centered on the figural aspects, on "rhetorical exhorbitancies" and on the illicit separation between words and things".
}

influential philosophers and the authoritative institutions, rhetorical ornaments are unfortunately pinned down to the superficial adorning business. Then in the following translation of the Greco-Roman rhetorical classics, the non-equivalent English "ornament" has to be used for the Latin "ornamentum", leading the unfortunate readers to the severe misunderstanding of the original scope. This inevitable language contact, with the overwhelming power of the modern English, may have contributed still further to the restrictive and pejorative construal of the original concept.

\section{Conclusions}

With the chronological surveying of 10 classics, we have demonstrated that "ornament" collocated with rhetorical figures was widely viewed as argumentative or inventional, especially from ancient Greece downward to the Renaissance. The cross-referencing of 5 most representative dictionaries further illustrates that this term gives priority to useful function at least in and before the medieval time and that it appears to turn increasingly aesthetic from the Enlightenment onwards. According to historical linguistics, the semantic change of "ornament" involves two tendency types: "Narrowing" and "Pejoration", which can be attributed mainly to cognitive (internal) and cultural (external) factors, and their possible interactions. This semantic change seems unavoidable and not without justification. We have to accept the destiny that today whenever we encounter "ornament", at least for the vast majority, the first association is beautiful decoration, rather than being useful or inventional. However, since the functions of rhetorical figures have proved to be argumentative far beyond mere beautification, not only by the ancient classics cited above, but increasingly by modern and contemporary scholarships (e.g. Joseph, 1947; Fahnenstock, 1999; Kraus, 2007; Harris, 2013). So here are our ways out: we can either avoid collocating tropes and schemes with "ornament", or add an attribute such as "argumentative", "inventional", "persuasive" before "ornament"--better even--with a more specific back modifier, such as "for ethos", "for pathos", or "for identification".

\section{Acknowledgements}

We would like to thank very gratefully, University of London (SOAS, UCL, Warburg, etc.) and British Library, for providing all the precious references; Randy Allen Harris, Ines Tyson, Ming'an Luo and the meticulous peer reviewers, for benefiting this exploration in various ways. Further, this research has been generously supported by Jiangsu Government Scholarship for Overseas Studies (JS-2016-214) and Chinese National Social Science Fund Project: "On Argumentative Textual Functions of Major Tropes and Schemes" (15BYY178). 


\section{REFERENCES}

[1] Alberic of Monte Cassino. 1973. Flowers of Rhetoric. In Miller, Joseph, Prosser, Michael, \& Benson, Thomas (eds). Readings in Medieval Rhetoric. Bloomington: Indiana University Press, pp., 131-161.

[2] Barnhart, R. 1966. Chambers Dictionary of Etymology. Oxford: Oxford University Press.

[3] Bizzell, P., \& Herzberg, B. 2001. The Rhetorical Tradition: Readings from Classical Times to the Present. Boston: Bedford/St. Martin's.

[4] Blair, H. 1819. Lectures on Rhetoric and Belles Lettres (Vol. I, Thirteenth Ed.). London: Bibliolife.

[5] Chantrell, G. 2002. The Oxford Dictionary of Word Histories. Oxford: Oxford University Press.

[6] [Cicero]. 1981. Rhetorica ad Herennium. Trans. Harry Caplan. Cambridge, MA: Harvard University Press.

[7] Conley, T. 1990. Rhetoric in the European Tradition. Chicago: The University of Chicago Press.

[8] Crespo, B. 2013. Change in Life, Change in Language: A Semantic Approach to the History of English. Frankfurt: Peter Lang $\mathrm{GmbH}$.

[9] Dillon, J., \& Gergel, T. 2003. The Greek Sophists. London: Penguin Books Ltd.

[10] Dyck, J. 1966. Ticht-Kunst: Deutsche Barockpoetik und rhetorische Tradition. Bad Homburg: Max Niemeyer Verlag.

[11] Fahnestock, J. R. 1999. Rhetorical figures in science. New York: Oxford University Press.

[12] France, P. 2006. Rhetoric. In The Cambridge History of Eighteenth-Century Philosophy (Vol. I), Haakonssen, Knud (ed.) Cambridge: Cambridge University Press. 496-515.

[13] Gove, P. B. 2002. Webster's Third New International Dictionary. Springfield: Merriam-Webster INC., Publishers.

[14] Griffin, R. 1969. Coronation of the Poet: Joachim du Bellay's Debt to the Trivium. Berkeley: University of California Press.

[15] Harris, R. A. 2013. Figural Logic in Gregor Mendal's "Experiments on Plant Hybrids". Philosophy and Rhetoric 46 (4), pp. 570-602.

[16] Harwood, J. T. 1986. The Rhetorics of Thomas Hobbes and Bernard Lamy. Carbonale: Southern Illinois University Press.

[17] Isocrates. 1929. Isocrates (II). Trans. George Norlin, London: William Heinemann LTD.

[18] Johnson, S. 1827. A Dictionary of the English Language. London: Longman.

[19] Joseph, M. 1947. Shakespeare's Use of the Arts of Language. New York: Columbia University Press.

[20] Kennedy, G. 1969. Quintilian. New York: Twayne Publishers, Inc.

[21] Kraus, M. 2007. From Figure to Argument: Contrarium in Roman Rhetoric. Argumentation 21, pp. 3-19.

[22] Ong, W. J. 1958. Ramus: Method and the Decay of Dialogue. Cambridge: Harvard University Press.

[23] Peacham, H. 1593. The Garden of Eloquence. London: British Library.

[24] Quintilian. 1921. The Institutio Oratoria. Trans. H. E. Butler. Vol. III. London: William Heinemann LTD.

[25] Simpson, J. A., \& Weiner, E. S. C. 1989. The Oxford English Dictionary. Oxford: Clarendon Press.

[26] The Venerable Bede. 1973. Concerning Figures and Tropes. In Miller, Joseph, Prosser, Michael, \& Benson, Thomas (eds). Readings in Medieval Rhetoric. Bloomington: Indiana University Press, pp. 96-122.

[27] Traugott, E., \& Dasher, R. 2002. Regularity in Semantic Change. Cambridge: Cambridge University Press.

[28] Vickers, B. 1988. In Defence of Rhetoric. Oxford: Clarendon.

[29] Wilson, T. 1994. The Art of Rhetoric (1560). University Park: The Pennsylvania State University Press. 